\title{
CRISPR/Cas12a Technology Combined with RT-ERA for Rapid and Portable SARS-CoV-2 Detection
}

\author{
Sihua Liu ${ }^{1} \cdot$ Mengqian Huang ${ }^{1} \cdot$ Yanan $\mathrm{Xu}^{1} \cdot$ Jun Kang ${ }^{1,5} \cdot$ Sheng $\mathrm{Ye}^{1,5} \cdot \mathrm{Si} \mathrm{Liu}^{1,5} \cdot$ Zhiyun Wang $^{2} \cdot$ \\ Hongyun $\mathrm{Liu}^{1} \cdot$ Jibin $\mathrm{Yu}^{3} \cdot$ Kongxin $\mathrm{Hu}^{4}$ (1) $\cdot$ Tao Wang ${ }^{1,5}$ (1)
}

Received: 24 November 2020 / Accepted: 28 March 2021 / Published online: 2 June 2021

(C) Wuhan Institute of Virology, CAS 2021

\section{Dear Editor,}

The outbreak and rapid spread of the new coronavirus, severe acute respiratory syndrome coronavirus 2 (SARS$\mathrm{CoV}-2)$, have resulted in more than 120 million confirmed infections and 2 million deaths worldwide as of March 2021. The statistical data were from WHO COVID-19 Explorer (https://worldhealthorg.shinyapps.io/covid/). The virus is also responsible for billions of US dollars in economic losses and has attracted great concern about public health safety worldwide. Generally, patients who have been infected with SARS-CoV-2 have symptoms such as fever, dry cough, dyspnea, acute respiratory distress syndrome, and septic shock (Chen et al. 2020; Wu et al. 2020). SARS-CoV-2 has a strong capacity to survive and spread in respiratory droplets and aerosols, and it is essential to diagnose suspected cases accurately in the early stage of infection to avoid widespread infection. Here, we developed a nucleic acid molecular detection system targeting the $N$ gene and ORFlab gene for SARS-CoV-2 detection

Supplementary Information The online version contains supplementary material available at https://doi.org/10.1007/s12250021-00406-7.

Tao Wang

wangtaobio@tju.edu.cn

$\triangle$ Kongxin Hu

hukongxin@caiq.gov.cn

1 School of Life Sciences, Tianjin University, Tianjin 300072, China

2 School of Environmental Science and Engineering, Tianjin University, Tianjin 300072, China

3 GenDx Biotech Co. Ltd, Suzhou 215000, China

4 Institute of Health Quarantine, Chinese Academy of Inspection and Quarantine, Beijing 100123, China

5 Institute of Tianjin Key Laboratory of Function and Application of Biological Macromolecular Structures, Tianjin 300072, China with CRISPR/Cas12a technology. This method has the advantages of high sensitivity and specificity due to the use of CRISPR/Cas12a technology, and it can be used for onsite testing with a portable testing instrument or immunochromatographic strips.

At present, the detection methods for SARS-CoV-2 are mainly focused on pathogen detection (Chu et al. 2020; ElTholoth et al. 2020; Zhou et al. 2020), serological detection (Li et al. 2020; Zhang et al. 2020), and chest imaging detection (Xie et al. 2020). Every method has limitations; qRT-PCR, the gold standard for COVID-19 diagnosis (Chu et al. 2020) that is currently widespreadly used in laboratory and clinical detection, has a detection limit of 1 copy $/ \mu \mathrm{L}$ (Supplementary Fig. S1A). However, due to its strict environmental requirements, qRT-PCR is not suitable for on-site detection, especially in public places such as airports, train stations, and seaports. Isothermal amplification technology (LAMP), such as real time LAMP (RT-LAMP), which greatly reduces detection cost and has relatively simple equipment requirements, is considered to be fit for on-site pathogen detection (Huang et al. 2020; Yan et al. 2020). The clustered regularly interspaced short palindromic repeats (CRISPR/Cas) based nucleic acid detection technology was developed to have the advantages of rapidity, simplicity, and low cost (Chen et al. 2018; Gootenberg et al. 2018). Combined detection systems have been applied to the detection of SARS-CoV-2, such as the CRISPR-based DETECTR method (Broughton et al. 2020) and the Cas13-based SHERLOCK system (Patchsung et al. 2020), which have their own advantages and disadvantages in detection conditions, time, and sensitivity (Table 1). RT-ERA reverses the template RNA into cDNA using the modified RNA reverse transcriptase. At the same time, the DNA recombinase combines with the primers to form a protein-DNA complex. The complex searches for and recognizes the homologous sequences in the cDNA and starts DNA synthesis (Xia and Chen 2020). The system amplifies specific genes exponentially within $20-30 \mathrm{~min}$ at constant temperature $\left(37^{\circ} \mathrm{C}-\right.$ 
Table 1 Comparison of detection methods for SARS-CoV-2

\begin{tabular}{|c|c|c|c|c|c|c|}
\hline $\begin{array}{l}\text { Detection } \\
\text { systems }\end{array}$ & Target & $\begin{array}{l}\text { Detection } \\
\text { sensitivity } \\
(\text { copies } / \mu \mathrm{L})\end{array}$ & $\begin{array}{l}\text { Assay reaction } \\
\text { time } \\
\text { (approximate) }\end{array}$ & Assay components & $\begin{array}{l}\text { Bulky } \\
\text { instrumentation } \\
\text { required }\end{array}$ & Reference \\
\hline $\begin{array}{c}\text { OneStep RT- } \\
\text { PCR assay }\end{array}$ & $N$ gene & 1 & $90 \mathrm{~min}$ & $\begin{array}{l}\text { Denature }\left(50{ }^{\circ} \mathrm{C}, 15 \mathrm{~min} ; 94{ }^{\circ} \mathrm{C}, 15 \mathrm{~min}\right) \\
\text { amplification }\left(94{ }^{\circ} \mathrm{C}, 15 \mathrm{~s} ; 55^{\circ} \mathrm{C}, 45 \mathrm{~s} \text {; }\right. \\
45 \text { cycles })\end{array}$ & Yes & This study \\
\hline \multirow[t]{2}{*}{ RT-LAMP } & $\begin{array}{l}\text { ORFlab gene } \\
S \text { gene }\end{array}$ & $\begin{array}{l}10(\text { ORF } 1 a b) \\
100(S)\end{array}$ & $60 \mathrm{~min}$ & RT-LAMP $\left(63{ }^{\circ} \mathrm{C}\right.$ for $\left.60 \mathrm{~min}\right)$ & No & $\begin{array}{l}\text { Yan et al. } \\
\quad(2020)\end{array}$ \\
\hline & $\begin{array}{l}\text { ORFlab gene } \\
S \text { gene } \\
N \text { gene }\end{array}$ & 0.08 & $30 \mathrm{~min}$ & RT-LAMP $\left(65^{\circ} \mathrm{C}\right.$ for $\left.30 \mathrm{~min}\right)$ & No & $\begin{array}{l}\text { Huang } \\
\text { et al. } \\
\quad(2020)\end{array}$ \\
\hline $\begin{array}{l}\text { RT-LAMP/ } \\
\text { Cas12 }\end{array}$ & $\begin{array}{l}E \text { gene } \\
N \text { gene }\end{array}$ & 10 & $30-40 \mathrm{~min}$ & $\begin{array}{l}\text { RT-LAMP }\left(62{ }^{\circ} \mathrm{C}, 20-30 \mathrm{~min}\right) \\
\text { Cas } 12\left(37^{\circ} \mathrm{C}, 10 \mathrm{~min}\right)\end{array}$ & No & $\begin{array}{l}\text { Broughton } \\
\text { et al. } \\
\text { (2020) }\end{array}$ \\
\hline $\begin{array}{l}\text { Cas13-based } \\
\text { SHERLOCK } \\
\text { system }\end{array}$ & $\begin{array}{l}S \text { gene } \\
\text { ORFlab gene } \\
N \text { gene }\end{array}$ & $\begin{array}{l}46.2(S \text { gene } \\
\text { highest } \\
\text { sensitivity })\end{array}$ & $60 \mathrm{~min}$ & $\begin{array}{l}\text { RT-RPA }\left(42{ }^{\circ} \mathrm{C}, 25 \mathrm{~min}\right) \\
\text { Cas13 }\left(37^{\circ} \mathrm{C}, 30-60 \mathrm{~min}\right)\end{array}$ & No & $\begin{array}{l}\text { Patchsung } \\
\quad \text { et al. } \\
\text { (2020) }\end{array}$ \\
\hline RT-ERA & $N$ gene & 10 & $80 \mathrm{~min}$ & $\begin{array}{l}\text { RT-ERA }\left(39^{\circ} \mathrm{C}, 30 \mathrm{~min}\right) \\
\text { Purification }\left(56^{\circ} \mathrm{C}, 5 \mathrm{~min}\right) \\
\text { Agarose gel electrophoresis }(45 \mathrm{~min})\end{array}$ & No & This study \\
\hline $\begin{array}{l}\text { Cas12a-based } \\
\text { RT-ERA } \\
\text { system }\end{array}$ & $\begin{array}{l}N \text { gene } \\
\text { ORFlab gene }\end{array}$ & $\begin{array}{l}0.25(N) \\
0.5(\text { ORF } 1 a b)\end{array}$ & $40 \mathrm{~min}$ & $\begin{array}{l}\text { RT-ERA }\left(39{ }^{\circ} \mathrm{C}, 30 \mathrm{~min}\right) \\
\text { Cas12a }\left(37^{\circ} \mathrm{C}, 10 \mathrm{~min}\right)\end{array}$ & No & This study \\
\hline
\end{tabular}

$42{ }^{\circ} \mathrm{C}$ ) with a sensitivity of 20 copies of SARS-CoV$2 N$ gene per reaction (Supplementary Fig. S1B). In this article, we combined RT-ERA with CRISPR/Cas12a to create a rapid and portable SARS-CoV-2 detection system. When the amplification system is added to the CRISPR/ Cas12a system, Cas12a proteins cleave double-stranded DNA (dsDNA) with the specific crRNA guide, inducing robust, non-specific single-stranded DNA (ssDNA) transcleavage, but the specific cleavage mechanism is still unclear (Li et al. 2018). The ssDNA reporter fluoresces when the quenched fluorescent ssDNA is cleaved. We used a portable fluorescence constant temperature amplification instrument, namely the GS8 Isothermal Cycle, or immunochromatographic strips to collect and analyze fluorescence signals (Fig. 1A).

Based on the sequence provided by the China CDC, we designed a specific crRNA for $N$ and ORFlab gene, which could be used to distinguish SARS-CoV-2 from other coronaviruses (SARS-CoV, MERS-CoV, HCoV-NL63, HCoV-229E, HCoV-OC43, HKU1, MHV, and IBV) (Supplementary Fig. S1C). And in order to improve the sensitivity of the detection system, we optimized the amplification and detection system to improve the amplification efficiency and shorten the detection time. In addition, we used a portable fluorescence isothermal amplification instrument, which is advantageous in its small size, easy operation, and automatic positive signal detection. Thus, the portable fluorescence isothermal amplification instrument is considered a good choice for on-site SARS-CoV-2 detection. This testing system can be used for on-site SARS-CoV-2 detection with a sensitivity of 7.5 copies of SARS-CoV-2 $N$ gene and 15 copies of SARS-CoV-2 ORF lab gene per $30-\mu \mathrm{L}$ reaction (Fig. 1B), and the entire detection process takes only $40 \mathrm{~min}$. The results of the cross-reactivity test with other tested viruses indicated that the SARS-CoV-2 CRISPR/Cas12a detection system had great specificity (Fig. 1C and Supplementary Fig. S1D). The results of CRISPR/Cas12a assay were in $100 \%$ agreement with qRT-PCR, meaning it correctly identified and differentiated all 20 positive samples and five negative samples, which were recruited from the Chinese Academy of Inspection and Quarantine (Beijing). (Fig. 1D-1F). There was no difference between the detection results of CRISPR/Cas12a and qRT-PCR detection for SARS-CoV-2. In order to simplify the field test equipment, we also combined the CRISPR/Cas12a system and immunochromatographic strips for detection (Fig. 1G). Although the band density was weak, there was a significant difference between the samples and the negative control group. It was demonstrated that the system has good sensitivity. We speculate that prolonging the incubation time may solve the problem of weak band density. 


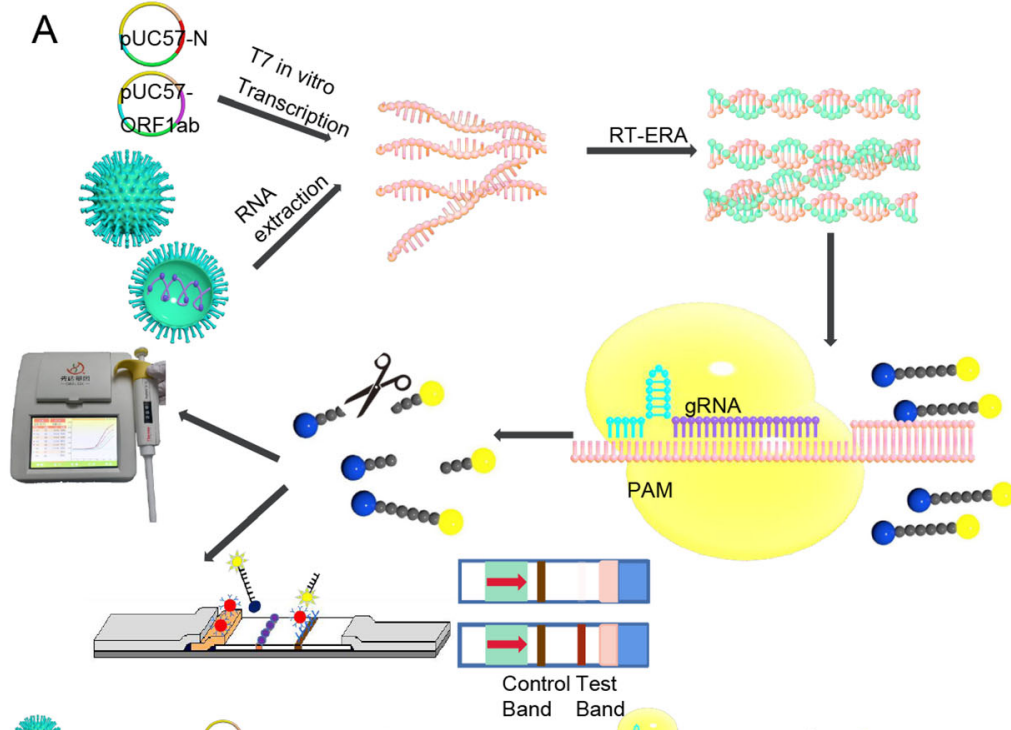

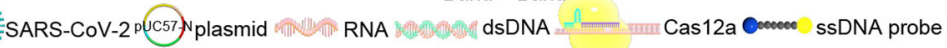

Au-NP anti-FAM antibody Streptavidin FAM Biotin Y Anti-Mouse antibody

D
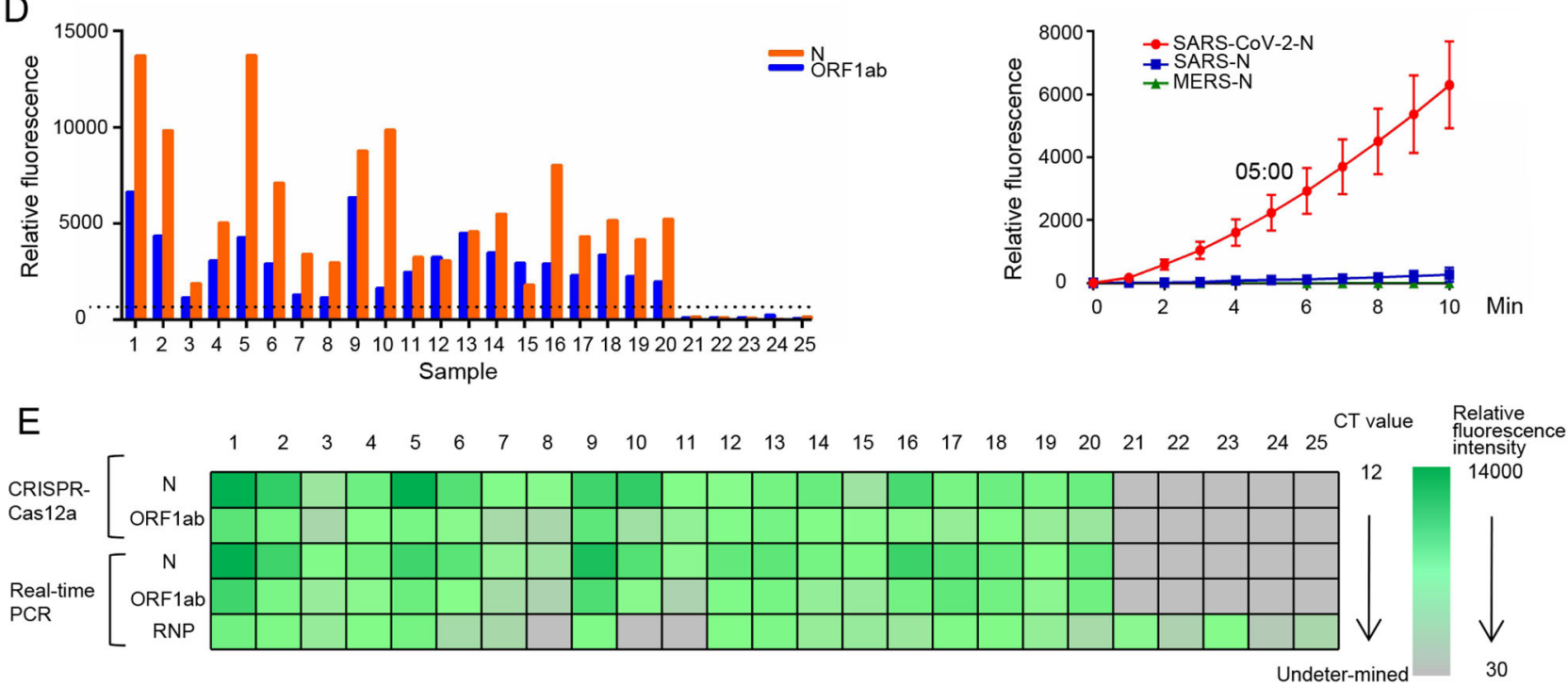

F

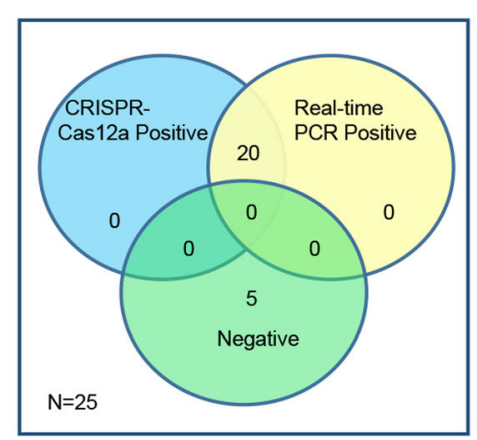

B

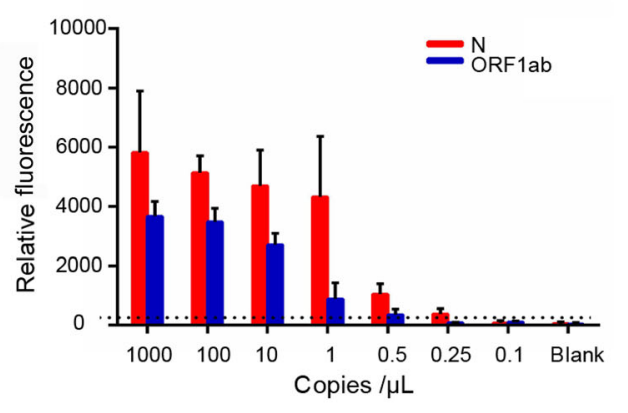

C
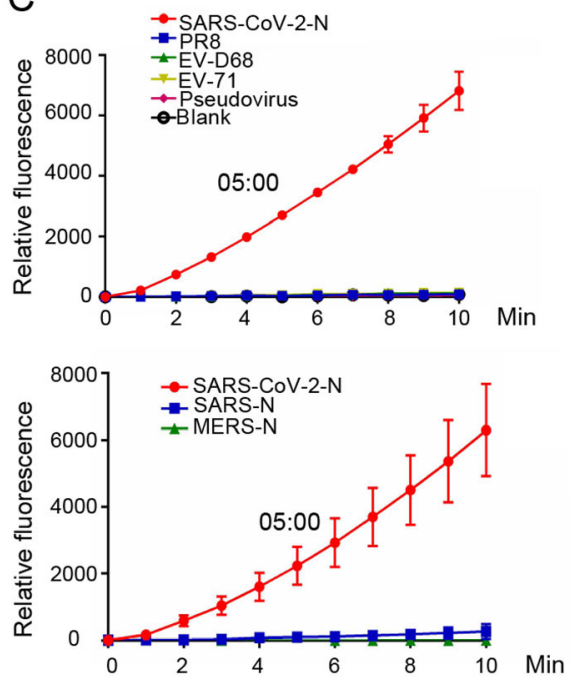

G

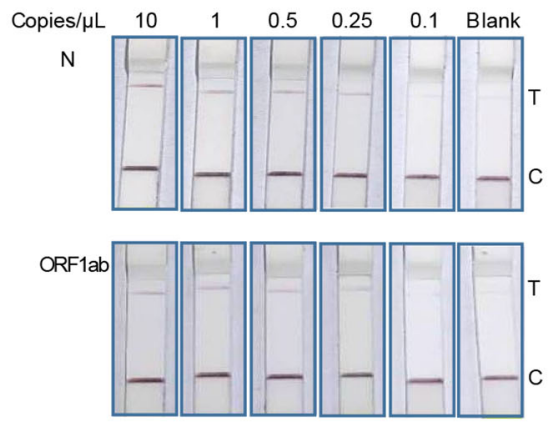

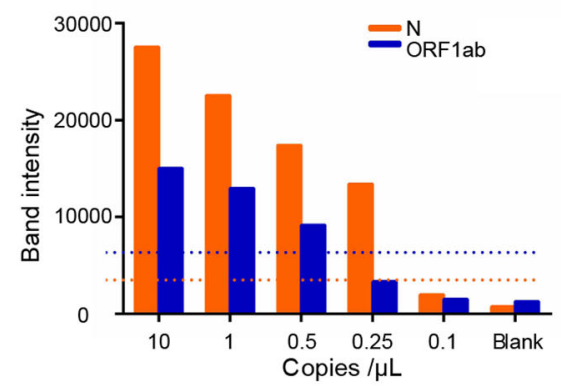


4Fig. 1 CRISPR/Cas12a technology combined with RT-ERA for SARS-CoV-2 detection. A Schematic diagram of Cas12a-mediated SARS-CoV-2 detection. The SARS-CoV-2 RNA transcribed in vitro or extracted from the virus was amplified by RT-ERA. After Cas12a was identified and combined with dsDNA under the guidance of crRNA, Cas12a randomly cleaved ssDNA FQ probe (F, fluorophore; $\mathrm{Q}$, quencher), and then the fluorescence signal was collected by the GS8 Isothermal Cycler or immunochromatographic strips. B The histogram shows the sensitivity of CRISPR/Cas12a combined with RT-ERA for detection of $N$ and ORFlab genes at $10 \mathrm{~min}$. Serially diluted synthetic SARS-CoV-2 RNA was used as a template. C The RNA of SARS-CoV-2 (100 copies/ $\mu \mathrm{L}, N$ gene), influenza virus PR8 strain, enterovirus D68 (EV-D68), enterovirus 71 (EV71), and pseudovirus were amplified by RT-ERA and detected by the CRISPR/Cas12a system (upper panel). The $N$ gene fragments of SARS and MERS were obtained by $\mathrm{T} 7$ transcription in vitro and detected as described above (lower panel). D The RNA was extracted from 25 clinical pharyngeal swabs and preamplified with RT-ERA for $30 \mathrm{~min}$. The fluorescence signal was detected by the CRISPR/Cas12a system for $10 \mathrm{~min}$. $\mathbf{E}$ The relative fluorescence value and $\mathrm{Ct}$ value of each clinical sample are displayed by a color scale diagram. F The Venn diagram shows the consistency between the CRISPR/Cas12a assay and the qRT-PCR assay. G The sensitivity of CRISPR/Cas12a combined with immunochromatographic strips for detection of $N$ and ORFlab genes (left panel). Serially diluted synthetic SARS-CoV-2 RNA was used as a template. The visualization of sample test band intensity was quantified by ImageJ and GraphPad (right panel)

In addition, the combination system also helped to ease the requirements of instruments for on-site detection. We showed that the combination of fluorescence detection and immunochromatographic strip detection was fast and had good sensitivity, and the detection of clinical samples could achieve 100\% accuracy with qRT-PCR detection results (Fig. 1D-1F).

In summary, to promote the accurate diagnosis of suspected cases in the early stage of infection, we developed a rapid, highly sensitive, convenient SARS-CoV-2 detection method that utilizes RT-ERA amplification and the CRISPR/Cas12a system. This testing system can be used for on-site SARS-CoV-2 detection with a sensitivity of 7.5 copies of SARS-CoV-2 $N$ gene and 15 copies of SARSCoV-2 ORFlab gene per $30-\mu \mathrm{L}$ reaction in $40 \mathrm{~min}$. Finally, we simplified the requirements for on-site detection instruments by using the CRISPR/Cas12a method combined with immunochromatographic strips, resulting in a powerful and effective tool for on-site detection of SARS-CoV-2 with high sensitivity and low cost.

Acknowledgements We thank Y.-C. Zeng (Chinese Academy of Inspection and Quarantine) for technical advice. This work was supported by the National Key Research and Development Program of China (2017YFA0205102) and two independent innovation Foundations of Tianjin University (2020XY-0078 and 2020XY0060).

\section{Compliance with Ethical Standards}

Conflict of interest All authors declare that they have no competing interests.

Informed consent This study was approved by the local ethics committee of Tianjin University. Written informed consent was waived due to the rapid emergence of this infectious disease.

\section{References}

Broughton JP, Deng X, Yu G, Fasching CL, Servellita V, Singh J, Miao X, Streithorst JA, Granados A, Sotomayor-Gonzalez A, Zorn K, Gopez A, Hsu E, Gu W, Miller S, Pan CY, Guevara H, Wadford DA, Chen JS, Chiu CY (2020) CRISPR-Cas12-based detection of SARS-CoV-2. Nat Biotechnol 38:870-874

Chen JS, Ma E, Harrington LB, Da Costa M, Tian X, Palefsky JM, Doudna JA (2018) CRISPR-Cas12a target binding unleashes indiscriminate single-stranded DNase activity. Science 360:436-439

Chen N, Zhou M, Dong X, Qu J, Gong F, Han Y, Qiu Y, Wang J, Liu Y, Wei Y, Xia J, Yu T, Zhang X, Zhang L (2020) Epidemiological and clinical characteristics of 99 cases of 2019 novel coronavirus pneumonia in Wuhan, China: a descriptive study. Lancet 395:507-513

Chu DKW, Pan Y, Cheng SMS, Hui KPY, Krishnan P, Liu Y, Ng DYM, Wan CKC, Yang P, Wang Q, Peiris M, Poon LLM (2020) Molecular diagnosis of a novel coronavirus (2019-nCoV) causing an outbreak of pneumonia. Clin Chem 66:549-555

El-Tholoth M, Bau HH, Song J (2020) A single and two-stage, closed-tube, molecular test for the 2019 novel coronavirus (COVID-19) at home, clinic, and points of entry. ChemRxiv https://doi.org/10.26434/chemrxiv.11860137.v1

Gootenberg JS, Abudayyeh OO, Kellner MJ, Joung J, Collins JJ, Zhang F (2018) Multiplexed and portable nucleic acid detection platform with Cas13, Cas12a, and Csm6. Science 360:439-444

Huang WE, Lim B, Hsu CC, Xiong D, Wu W, Yu Y, Jia H, Wang Y, Zeng Y, Ji M, Chang H, Zhang X, Wang H, Cui Z (2020) RTLAMP for rapid diagnosis of coronavirus SARS-CoV-2. Microb Biotechnol 13:950-961

Li SY, Cheng QX, Liu JK, Nie XQ, Zhao GP, Wang J (2018) CRISPR-Cas12a has both cis- and trans-cleavage activities on single-stranded DNA. Cell Res 28:491-493

Li Z, Yi Y, Luo X, Xiong N, Liu Y, Li S, Sun R, Wang Y, Hu B, Chen W, Zhang Y, Wang J, Huang B, Lin Y, Yang J, Cai W, Wang X, Cheng J, Chen Z, Sun K, Pan W, Zhan Z, Chen L, Ye F (2020) Development and clinical application of a rapid IgM-IgG combined antibody test for SARS-CoV-2 infection diagnosis. J Med Virol 92:1518-1524

Patchsung M, Jantarug K, Pattama A, Aphicho K, Suraritdechachai S, Meesawat P, Sappakhaw K, Leelahakorn N, Ruenkam T, Wongsatit T, Athipanyasilp N, Eiamthong B, Lakkanasirorat B, Phoodokmai T, Niljianskul N, Pakotiprapha D, Chanarat S, Homchan A, Tinikul R, Kamutira P, Phiwkaow K, Soithongcharoen S, Kantiwiriyawanitch C, Pongsupasa V, Trisrivirat D, Jaroensuk J, Wongnate T, Maenpuen S, Chaiyen P, Kamnerdnakta S, Swangsri J, Chuthapisith S, Sirivatanauksorn Y, Chaimayo C, Sutthent R, Kantakamalakul W, Joung J, Ladha A, Jin X, Gootenberg JS, Abudayyeh OO, Zhang F, Horthongkham N, Uttamapinant C (2020) Clinical validation of a Cas13- 
based assay for the detection of SARS-CoV-2 RNA. Nat Biomed Eng 4:1140-1149

Wu D, Wu T, Liu Q, Yang Z (2020) The SARS-CoV-2 outbreak: what we know. Int J Infect Dis 94:44-48

Xia S, Chen X (2020) Single-copy sensitive, field-deployable, and simultaneous dual-gene detection of SARS-CoV-2 RNA via modified RT-RPA. Cell Discov 6:37

Xie X, Zhong Z, Zhao W, Zheng C, Wang F, Liu J (2020) Chest CT for typical coronavirus disease 2019 (COVID-19) pneumonia: relationship to negative RT-PCR testing. Radiology 296:E41e45

Yan C, Cui J, Huang L, Du B, Chen L, Xue G, Li S, Zhang W, Zhao L, Sun Y, Yao H, Li N, Zhao H, Feng Y, Liu S, Zhang Q, Liu D, Yuan J (2020) Rapid and visual detection of 2019 novel coronavirus (SARS-CoV-2) by a reverse transcription loopmediated isothermal amplification assay. Clin Microbiol Infect 26:773-779

Zhang W, Du RH, Li B, Zheng XS, Yang XL, Hu B, Wang YY, Xiao GF, Yan B, Shi ZL, Zhou P (2020) Molecular and serological investigation of 2019-nCoV infected patients: implication of multiple shedding routes. Emerg Microbes Infect 9:386-389

Zhou P, Yang XL, Wang XG, Hu B, Zhang L, Zhang W, Si HR, Zhu Y, Li B, Huang CL, Chen HD, Chen J, Luo Y, Guo H, Jiang RD, Liu MQ, Chen Y, Shen XR, Wang X, Zheng XS, Zhao K, Chen QJ, Deng F, Liu LL, Yan B, Zhan FX, Wang YY, Xiao GF, Shi ZL (2020) A pneumonia outbreak associated with a new coronavirus of probable bat origin. Nature 579:270-273 